\title{
GREEN MEDICINE: USING LESSONS FROM TORT LAW AND ENVIRONMENTAL LAW TO HOLD PHARMACEUTICAL MANUFACTURERS AND AUTHORIZED DISTRIBUTORS LIABLE FOR INJURIES CAUSED BY COUNTERFEIT DRUGS
}

\author{
Stephanie Feldman Aleong*
}

\section{INTRODUCTION}

The majority of the American public would be astonished by the frequency with which counterfeit prescription drugs appear on reputable drug store shelves. In 2004, the Food and Drug Administration (FDA) noted that those who counterfeit prescription drugs "deny ill patients the therapies that can alleviate suffering and save lives." In 2006, the World Health Organization (WHO) estimated that there exists a $\$ 30$ billion market in fake drugs. $^{2}$ Although the FDA has tried to characterize the incidence of

\footnotetext{
* Stephanie Feldman Aleong is an Assistant Professor of Law and the Director of the Masters of Science in Health Law Program at Nova Southeastern University, Shepard Broad Law Center, in Ft. Lauderdale, Florida. Prior to becoming an academic, Professor Aleong was Florida's Health Care Fraud Priority Leader in the Office of the Statewide Prosecutor. She also serves on the Advisory Board for Secure Symbology, Inc., a technology company aimed at bar-coding many products to enhance inventory control and safety. Professor Aleong first presented the concept of this Article at the American Society of Law, Medicine and Ethics' 30th Annual Health Law Professors' Conference and later made the same presentation as a Young Scholar at the Southeastern Association of Law Schools' Annual Conference. Professor Aleong would like to thank Professor Joel A. Mintz, Professor Michael Flynn, and Professor Kathy Cerminara, her colleagues at NSU, for their review and discussion of this article. She also thanks her SEALS mentor, Professor Steven Ellman, New York Law School, for his guidance. Finally, Professor Aleong would like to thank students Michael Pascucci and Laura Cancilla for their efforts as her research assistants.

1. U.S. Food \& Drug Admin., Combating Counterfeit Drugs: A Report of the Food And DRUG ADMINISTRATION i (2004), available at http://www.fda.gov/oc/initiatives/counterfeit/report02_04.pdf [hereinafter FDA REPORT 2004]. The FDA even noted that, in some countries, the problem was so overwhelming that many patients had a better chance of getting fake medicine than authentic drugs. Id.

2. In some of the more impoverished states, these fake "medicines" constitute $30 \%$ of the prescription drug market. MSNBC.com, WHO to Crack Down on Fake Drugs, http://www.msnbc .msn.com/id/15730101 (last visited Jan. 23, 2008). In late 2006, the WHO created a taskforce entitled "IMPACT" (International Medical Products Anti-Counterfeiting Taskforce) to "put a stop to the deadly trade in fake drugs, which studies suggest kill thousands of people every year." William Burns, WHO Launches Taskforce to Fight Counterfeit Drugs, 84 Bull. World Health Org. 689, 689 (2006), available at http:/www.who.int/entity/bulletin/volumes/84/9/news.pdf. In 2003, the WHO conducted a study and determined that global sales of counterfeit drugs amounted to an estimated $\$ 32$ billion, constituting $10 \%$ of all medicines sold worldwide. Ronald W. Buzzeo, Counterfeit Pharmaceuticals and
} 
counterfeit medications in the United States prescription drug marketplace as "rare,"3 numerous instances of counterfeit drugs reaching consumers from the shelves of large, retail pharmacy chains have been well-documented. ${ }^{4}$ As a result, the FDA has lifted the stay on a nearly fifteen-year-old regulation that requires distributors of prescription drugs to document the sources of the drugs they peddle. ${ }^{5}$ In fact, the high risk of receiving fake or diverted drugs in the United States has been referred to as "pharmaceutical roulette" for millions of American patients. ${ }^{6}$

Moreover, the incidence of counterfeit drugs is a growing problem in the United States. The Pharmaceutical Security Institute reported that the value of seized, counterfeit, and diverted ${ }^{7}$ drugs in this country approached $\$ 200$ million in 2003, a sevenfold increase from 2002. ${ }^{8}$ Further, the United States Drug Intelligence Center (NDIC) reports that in $2006,78.8 \%$ of state and local law enforcement agencies reported moderate to high availability of illicit pharmaceuticals in their jurisdictions. ${ }^{9}$

the Public Health, WAll ST. J., Oct. 4, 2005, at A20.

3. FDA REPORT 2004, supra note 1, at i. The FDA claims that a "relatively comprehensive system of laws, regulations, and enforcement by [f]ederal and state authorities has kept drug counterfeiting rare" in the United States, but did acknowledge the growing problem of counterfeit drugs. Id. The FDA further remarked that the "exact prevalence rates [of counterfeit drugs] in the U.S. are not known." Id. at 2.

4. See, e.g., Katherine Eban, Dangerous Doses: How Counterfeiters Are Contaminating America's Drug Supply (2005). Eban details how counterfeit drugs emanating from hot trailers, car trunks, a Miami strip club and other questionable sources arrived on the shelves of drugstores like CVS. See id. at 359. In the interest of full disclosure, I was one of the prosecutors described in Ms. Eban's book as I worked on counterfeit drug prosecutions in my capacity as Florida's Health Care Fraud Priority leader. NBC's Dateline has also done investigative reporting on the prevalence of counterfeit drugs in the legitimate United States marketplace. Dateline NBC: Inside the World of Counterfeit Drugs (NBC television broadcast June 9, 2006) (transcript on file with the University of Pittsburgh Law Review).

5. Anna Wilde Mathews \& Heather Won Tesoriero, FDA to Order Tracking of Medicines, WALL St. J., June 9, 2006, at A2. The FDA lifted the stay on the "pedigree" requirement provided in 21 C.F.R. $\S 203.50$ (2007), which requires non-authorized distributors of pharmaceuticals to provide a document detailing the distribution history of a pharmaceutical.

6. Gilbert M. Gaul \& Mary Pat Flaherty, U.S. Prescription Drug System Under Attack, Wash. Post, Oct. 19, 2003, at A15. Middlemen divert expensive and popular drugs from the legitimate market into a shadow market where criminals introduce counterfeit medication and then move the drugs back into the mainstream distribution network. Id.

7. The term "diverted" indicates drugs that have strayed out of the distribution channel for which they were originally intended. Diverted drugs include those that were originally purchased by a government program such as Medicare, Medicaid, or the Veterans' Administration, and then resold into the legitimate market. U.S. Food \& Drug Admin., FDA's Counterfeit Drug Task Force Interim Report (2003), available at $\mathrm{http}: / / \mathrm{www} . f d a . g o v / o c / i n i t i a t i v e s / c o u n t e r f e i t / r e p o r t / i n t e r i m \_r e p o r t . h t m l$ [hereinafter FDA INTERIM REPORT 2003].

8. Buzzeo, supra note 2.

9. National Drug Intelligence Center, U.S. Department of Justice, National Drug Threat Assessment 2007, at 18 (2007), available at http://www.usdoj.gov/ndic/pubs21/21137/ 
The drug distribution system in the United States is porous and vulnerable. Drugs are usually not sold directly from a manufacturer to a dispensing pharmacy. ${ }^{10}$ Drugs weave their way through a complicated distribution chain that includes large and small distributors, authorized and non-authorized distributors, and even criminal hands before reaching dispensing pharmacies which might, in turn, sell unused product back into the distribution chain. ${ }^{11}$

This Article will consider the following: (1) How prescription drugs are distributed in the United States; (2) whether the law currently contains adequate safeguards to protect the integrity of the drug supply from counterfeiters; (3) how courts could hold manufacturers and authorized distributors vicariously liable for injuries caused by counterfeit drugs when such entities fail to take special precautions to avoid breaching a nondelegable duty of safe distribution; and (4) whether Congress should go beyond existing tort principles by imposing strict liability on manufacturers and distributors of pharmaceutical drugs when counterfeit drugs injure patients - much like the strict liability schemes for hazardous waste imposed by environmental laws such as the Resource Conservation and Recovery Act (RCRA) ${ }^{12}$ and the Comprehensive Environmental Response, Compensation and Liability Act (CERCLA). ${ }^{13}$ Much like the problem of hazardous waste, the occurrence of

21137p.pdf.

10. Gaul \& Flaherty, supra note 6, at A15. The "gold standard" for safe distribution existed when manufacturers sold directly to the three largest distributors in the country, which in turn sold directly to drug dispensing entities, thereby involving no other wholesalers in distribution. Id.

11. Regarding the seizure of more than 70,000 doses of counterfeit Viagra, Aaron Graham, who had been an investigator for both the government and for the pharmaceutical industry, commented to Dateline,

You might think medicines go straight from the factory to your pharmacy. But there's actually a complex network of wholesalers who buy and sell surplus medicines. All it takes is some phony paperwork and some realistic packaging to let fake medicine slip into the system, and be shipped to local pharmacies nationwide. And criminals know this.

Dateline NBC: Inside the World of Counterfeit Drugs, supra note 4.

12. 42 U.S.C. $\S \S 6901-6992 \mathrm{k}(2000)$.

13. 42 U.S.C. $\S \S 9601-9675$ (2000). 
counterfeit drugs is both foreseeable ${ }^{14}$ and the social byproduct of otherwise legitimate pharmaceutical manufacture and distribution.

\section{How Drugs Are Distributed in the United States}

Drugs in the United States generally do not travel straight from the line of production to the dispensing pharmacy. Rather, a serpentine maze provides a ripe environment for the infiltration of counterfeit, adulterated, and diverted drugs. ${ }^{15}$

The distribution system is primarily tiered among manufacturers, the "Big 3" distributors/drug wholesalers, secondary wholesalers, ${ }^{16}$ and repackagers. The FDA has identified three primary routes for drug sales in the United States, and each involves drugs passing through multiple hands, demonstrating the vulnerability of the distribution system to counterfeit, adulterated, and diverted products. ${ }^{17}$ The "Big 3" wholesalers - Cardinal Health, ${ }^{18}$ McKesson ${ }^{19}$

14. On May 6, 2005, Cardinal Health promised to discontinue its pharmaceutical arbitrage desk which bought and sold drugs among secondary wholesalers because of the high incidence of counterfeit drugs in the distribution network in the United States. Heather Won Tesoriero, Cardinal Health Ends Drug Trading, Wall St. J., May 6, 2005, at B2. Additionally, in its SEC filing on September 23, 2005, AmerisourceBergen Corporation promised that, effective October 1, 2005, it would purchase all of its branded and generic pharmaceuticals for distribution in the United States only from manufacturers. AmerisourceBergen Corp., Current Report, (Form 8-K), at Exhibit 99.1 (Sept. 23, 2005). "In the rare instances in which a manufacturer requires [AmerisourceBergen] to purchase products from an exclusive distributor, AmerisourceBergen [would] follow the manufacturer's requirements. This change [was] not expected to have a material impact on the company's fiscal year 2006 earnings." Id.

15. Corrupt wholesalers often solicit members of the distribution chain to resell discounted drugs to them for re-introduction into the nation's drug supply and often buy drugs from criminal enterprises. See EBAN, supra note 4, at 19-92.

16. Secondary wholesalers buy selected drug products from wholesalers, and then resell to other wholesalers, including large wholesalers, and pharmacies. FDA INTERIM REPORT 2003, supra note 7. However, some fifteen regional distributors, which represent billions of dollars in drug sales, do exist in addition to the "Big 3" distributors. EBAn, supra note 4, at 90.

17. The figure pictured below from the FDA Interim Report 2003 depicts the chains of drug distribution in the United States: 
and AmerisourceBergen, ${ }^{20}$ which collectively account for nearly $90 \%$ of the primary wholesale market ${ }^{21}$ — sell drugs into a distribution web containing large governmental agencies, secondary wholesalers, and criminal actors. ${ }^{22}$ "Repackagers" of drugs further obscure the origin of a particular drug when they break wholesale drugs in bulk containers into smaller units for sale to pharmacies or, conversely, re-aggregate smaller units purchased as overstock

\section{Drug Distribution Models}

1. Manufacturer $\longrightarrow$ Retailer

2. Manufacturer $\longrightarrow$ Wholesaler $\longrightarrow$ Retâiler

3. Manufacturer $\rightarrow$ Whofesaler $\rightarrow$

Repackager
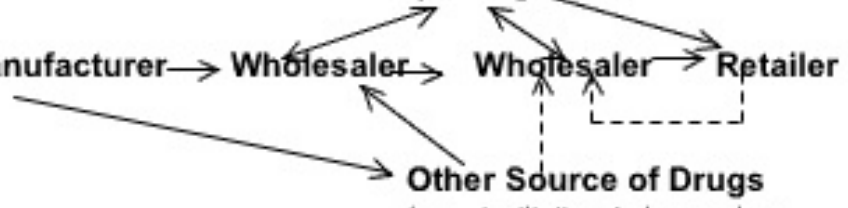

(e.g., institutional pharmacies, closed door pharmacies, foreign markets

[T]hree models showing the movement of drugs through the U.S. drug distribution system. (The dotted lines indicate potential illegal sales.) In the simplest situation, the manufacturer sells directly to a retailer. However, in many instances, there can be one or more wholesalers, or even a repackager, who handles the drug before it reaches the retailer. It is in these intermediate steps, particularly when the wholesaler(s) and/or repackager(s) obtain products from sources other than the original manufacturer, that the greatest opportunities for compromising the security of the U.S. distribution system exist.

FDA INTERIM REPORT 2003, supra note 7.

18. For fiscal year 2007, Cardinal Health reported $\$ 87$ billion in revenue and $\$ 1.4$ billion in operating earnings. CardinalHealth Inc., Annual Report (Form 10-K), at 27 (Aug. 24, 2007).

19. McKesson Corp. reported $\$ 88.1$ billion in operating revenue for fiscal year 2006. McKesson Corp., Annual Report (Form 10-K), at 25 (May 16, 2006).

20. AmerisourceBergen reported $\$ 56.7$ billion in operating revenue for fiscal year 2006 . AmerisourceBergen Corp., Annual Report (Form 10-K), at 26 (Dec. 8, 2006).

21. FDA InTERIM RePort 2003, supra note $7, \S 2$.

22. Id. 
from pharmacies into larger bundles for resale to wholesalers. ${ }^{23}$ Because of the multiple distributors and the repackaging, the true origin of drugs in this net remains obscure. ${ }^{24}$

Although the government and wholesalers have maintained that legitimate reasons exist for so many entities to be involved in the distribution of drugs, ${ }^{25}$ the primary factor fueling diversion that was identified in the legislative history of the Prescription Drug Marketing Act (PDMA) is the cycling of drugs from one entity to another before reaching dispensing pharmacies. ${ }^{26}$ The high cost of drugs, "virtually anonymous distribution channels," ${ }^{27}$ and high consumer demand compound the desire of counterfeiters to flood the marketplace with tainted drugs. The riches from such an illegal enterprise are great. ${ }^{28}$ One FDA official opined that "some of the experts are telling us it's more lucrative to sell a counterfeit drug than it is [to sell] a narcotic such as heroin." 29

This complex maze of distribution allows tainted medicine to penetrate the legitimate marketplace at multiple points. In all-too-familiar patterns, criminals sell counterfeit, diverted, and adulterated drugs to small, unscrupulous wholesalers which, in turn, introduce the drugs into the distribution network. As the FDA itself has recognized, criminals can now

23. Id.

24. Even the New York State Attorney General has become concerned with the integrity and source of drugs that circulate in this web. His concern was triggered after a Long Island, New York, teenager and liver transplant recipient purchased from a local CVS adulterated medication that had traveled through a Miami strip club, a trailer, a laundry room, and then ten other facilities before reaching the shelves at CVS. EBAN, supra note 4, at 358 chart. Shortly after his mother injected him with the adulterated Epogen, Fagan convulsed at home and suffered radiating pain throughout his body. Id. at 122-24. He continued having these reactions after each injection until a staff person at CVS warned his mother that several vials of counterfeit Epogen bearing the same lot number as Fagan's drug had been found. Id.

25. The FDA stated that legitimate price differentials available because of temporary overstocks of drugs and quick turnaround for the temporary needs of pharmacies were among reasons to include multiple wholesaling entities in the distribution chain. FDA INTERIM REPORT 2003, supra note 7, § 2(A). The lobbyist organization for wholesale distributors, Healthcare Distribution Management Association, maintains that wholesale distributors play a critical role in making sure that patients do not suffer from shortfalls of medication, although they admit that wholesalers have no responsibility for ensuring that sufficient quantities of drugs are manufactured initially. Healthcare Distribution Management Association, Product Availability/Drug Shortage, http://www.healthcaredistribution.org/issues_in_dist/product.asp (last visited Jan. 23, 2008).

26. S. ReP. No. 100-303, at 1-2 (1988); see also Prescription Drug Marketing Act of 1987, Pub. L. No. 100-293, 102 Stat. 95 (1988) (codified as amended at 21 U.S.C. $\S \S 301-399$ (2000 \& Supp. IV 2004)).

27. Buzzeo, supra note 2, at A20.

28. $I d$.

29. $I d$. 
introduce counterfeit drugs at any point in the distribution process..$^{30}$ A single counterfeiter can contaminate a nation's drug supply at multiple levels of distribution. ${ }^{31}$

Some may argue that the complicated system of distribution is "no one's fault." Nonetheless, manufacturers and major drug wholesalers are responsible for the establishment of the overly complex and unnecessarily obtuse web. The activities that occur in this web are not "beyond the control" 32 of manufacturers. Very clearly, manufacturers have voluntarily chosen not to engage in the business of distributing drugs to dispensing pharmacies. Further, they have chosen the group of distributors to which they sell. $^{33}$ In addition, the three major wholesalers decide for themselves from whom they buy and to whom they sell drugs. Until recently, the largest wholesalers maintained pharmaceutical arbitrage divisions that scavenged the marketplace, buying drugs from nearly all comers at the lowest expense

30. FDA INTERIM REPORT 2003, supra note 7, § 2(C).

31. In fact, Neil Spence, a high-level vice president of Cardinal Health, one of the three largest drug wholesalers in the United States, conspired with a drug counterfeiter and allowed thousands of doses of counterfeit plasma medicine into the back door of Cardinal Health, which were then distributed throughout the country. Indictment at 2-4, United States v. Carlow, No. 3:06-00047 (M.D. Tenn. Mar. 29, 2006) available at http://www.dangerousdoses.com/pdf/Robert_Neil_Spence_Indictment\%5B1\%5D.pdf. Spence was buying, on behalf of Cardinal Health, fragile plasma medicine from Michael Carlow, who trafficked in counterfeit and diverted medicine. Id. Another of America's largest distributors, AmerisourceBergen, was the subject of an FDA and FBI investigation regarding its illegal diversion of drugs into the secondary market to boost profits. Heather Won Tesoriero \& Gary Fields, FBI, FDA Investigate Big Drug Wholesaler, WaLl Sт. J., Sept. 19, 2003, at B1. That same drug counterfeiter, Michael Carlow, was not only indicted in Tennessee regarding his transactions with Cardinal Health but also pled guilty in Missouri for dealing in $\$ 42$ million of diverted Lipitor. News Release, Bradley J. Schlozman, United States Attorney, Western District of Missouri, Florida Business Owner Pleads Guilty to $\$ 42$ Million Lipitor Conspiracy (Nov. 3, 2006), available at http://www.usdoj.gov/usao/mow/news2006/carlow.ple.htm. The Department of Justice announced that the District Court for the Western District of Missouri could impose a sentence of up to five years on Michael Carlow for his involvement in the multi-million dollar counterfeit Lipitor scheme. Id. Carlow was also indicted in Florida for repackaging millions of dollars' worth of adulterated drugs in the laundry room of his home. Grand Jury Indictment No. 1, State v. Carlow, No. SC02-2645 (Fla. July 21, 2003), available at $\mathrm{http}: / /$ myfloridalegal.com/IndictmentCarlowetal.pdf (alleging numerous offenses relating to his trade in counterfeit, diverted, and adulterated drugs, including, inter alia, racketeering, conspiracy to commit racketeering, organized scheme to defraud, and fraud).

32. A lawyer at deKieffer \& Horgan argued that the "byzantine" system of pharmaceutical distribution is almost wholly beyond the control of manufacturers. Donald deKieffer, Trojan Drugs: Counterfeit and Mislabeled Pharmaceuticals in the Legitimate Market, 32 AM. J.L. \& MED. 325, 327 (2006).

33. EBAN, supra note 4, at 90 . Manufacturers and large pharmacy retailers profit greatly from this web of a distribution system that "allows them to centralize their selling and purchasing and save billions in distribution costs." Id. 
possible. ${ }^{34}$ Clearly, the largest stakeholders in the pharmaceutical industry determine how medicine is distributed.

\section{The Law Currently Does Not Contain Adequate Safeguards to Protect the Integrity of the Drug Supply from Counterfeiters}

\section{A. Ineffective and Unimplemented Federal Law: The Prescription Drug Marketing Act of 1987}

In 1987, the federal government specifically enacted the Prescription Drug Marketing Act (PDMA) ${ }^{35}$ to curb diversion of prescription drugs which endangers public health. ${ }^{36}$ With the passage of the PDMA, Congress sought to end the recycling of drugs through the complex distribution system. ${ }^{37}$ In the text of the public law itself, Congress lamented that the American public could not trust the integrity of the drugs marketed in the United States. ${ }^{38}$ Although it created no new effective provisions itself, the Act amended numerous

34. See supra note 14. In fact, when Cardinal Health announced it would stop purchasing products from secondary sources in May 2005, the company acknowledged the risks posed by these sources: Ridding itself of a profitable but problematic business Interest, Cardinal Health will shut down its Cardinal Health Pharmaceutical Trading operation, which buys and sells discounted and overstocked pharmaceuticals in the secondary distribution market. The move-announced in a letter to employees and suppliers May 6-follows recent legal action from New York State Attorney General Elliot Spitzer, who last month subpoenaed Cardinal and its two largest whole competitors as part of a high-profile investigation of drug sourcing, counterfeiting and the pharmaceutical supply chain.

deKiefer, supra note 32, at 328 n.24 (citing James Frederick, Cardinal latest wholesaler to curb secondary dealing, Drug Store News, May 23, 2005, at 8). McKesson has made no such pledge to discontinue purchasing drugs from the secondary market.

35. Prescription Drug Marketing Act of 1987, Pub. L. No. 100-293, 102 Stat. 95 (1988).

36. See S. REP. No. 100-303, at 1-2 (1988). "The purpose of the legislation is to curb operation of the diversion market for prescription drugs that operates outside of normal channels of distribution and makes it difficult to protect American consumers from mislabeled, subpotent, adulterated, expired, or counterfeit pharmaceuticals." Id. at 2.

37. EBAN, supra note 4, at 107.

38. In its statutory findings, Congress stated that:

(1) American consumers cannot purchase prescription drugs with the certainty that the products are safe and effective.

(2) The integrity of the distribution system for prescription drugs is insufficient to prevent the introduction and eventual retail sale of substandard, ineffective, or even counterfeit drugs.

(3) The existence and operation of a wholesale submarket, commonly known as the "diversion market," prevents effective control over or even routine knowledge of the true sources of prescription drugs in a significant number of cases.

Prescription Drug Marketing Act, $\S 2$. 
provisions of the Federal Food Drug and Cosmetics Act (FFDCA). ${ }^{39}$ The PDMA sought to curtail numerous ills that Congress felt were contributing to the proliferation of tainted drugs in the United States drug supply, including: (1) the existence of the wholesale diversion market; ${ }^{40}(2)$ the resale in large volume of wholesale-priced drugs by entities other than the manufacturer or initial purchaser, ${ }^{41}$ and (3) the illegal sale of adulterated drugs that began as physicians' samples. ${ }^{42}$

Among its amendments to the FFDCA, the PDMA required drug wholesalers which were not "authorized distributors of record" 43 to submit a statement identifying each sale of a drug in its lifetime before reaching a dispenser or being returned to a distributor. ${ }^{44}$ This identifying statement is commonly referred to as a "pedigree." ${ }^{45}$ Pedigrees provide a transparent history of the source of a drug along with leads to investigators who want to trace the source of bad drugs. ${ }^{46}$ The pedigree requirement was Congress's attempt to "restore accountability to the wholesale sector of the pharmaceutical market." 47

Regrettably, the imagined accountability in the drug supply chain promised by the PDMA was short-lived. Then-President Ronald Reagan's less-than-enthusiastic PDMA signing statement foreshadowed a sluggish FDA effort to implement such accountability. ${ }^{48}$ Predictably, in response to cries

39. See 21 U.S.C. $\S \S 301,331,333,353,381$ (2000). See generally 21 U.S.C. $\S \S 301-399$ (2000 \& Supp.VI 2006).

40. "The existence and operation of a wholesale submarket, commonly known as the 'diversion market,' prevents effective control over or even routine knowledge of the true sources of prescription drugs in a significant number of cases." Prescription Drug Marketing Act, § 2(3).

41. "The bulk resale of below wholesale priced prescription drugs by health care entities, for ultimate sale at retail, helps fuel the diversion market and is an unfair form of competition to wholesalers and retailers that must pay otherwise prevailing market prices." Id. § 2(7).

42. "The existing system of providing drug samples to physicians through manufacturer's representatives has been abused for decades and has resulted in the sale to consumers of misbranded, expired, and adulterated pharmaceuticals." Id. § 2(6).

43. Id. $\S 6(\mathrm{e})(1)$. The problematic elasticity of the definition of an authorized distributor is discussed below. See infra pp. 256-57.

44. Prescription Drug Marketing Act, §6(e)(1).

45. William McConagha, Associate General Counsel, U.S. Food \& Drug Admin., Brief Overview of Prescription Drug Marketing Act, Address at the Counterfeit Task Force Public Workshop/Vendor Display 19 (Feb. 9, 2006), available at http://www.fda.gov/oc/meetings/rfid/0209FDA1.pdf; see also EBAN, supra note 4, at 163.

46. See McConagha, supra note 45 , at 19-20. Eban notes that even dog breeders and car dealers must provide pedigrees of their wares. EBAN, supra note 4, at 163.

47. H.R. ReP. No. 100-76, at 16-17 (1987).

48. In his signing statement, the President said:

Finally, although the lack of traceability of drug products in the diversion market is a valid 
from wholesalers ${ }^{49}$ and manufacturers,${ }^{50}$ both claiming that forcing wholesalers to provide histories of drugs would cripple the industry out of existence, the FDA reduced the pedigree requirement ${ }^{51}$ to a mere guidance opinion, ${ }^{52}$ in effect staying the implementation of pedigrees. Through a prolonged ten-year rulemaking process and the following decade, the FDA

concern that I share, the magnitude of the public health problem created by diverted drugs is still not clear. I am therefore also concerned by the provisions of the bill requiring use of substantial amounts of scarce Federal public health resources to police these practices.

Statement on Signing the Prescription Drug Marketing Act of 1987, 24 Weekly Comp. Pres. Doc. 519 (Apr. 25, 1988).

49. In a Senate hearing before the passage of the PDMA, a representative of one of the wholesalers' lobbies likened having to source medicine to being required to source real estate, a process which would make the cost of drugs dramatically higher and would be operationally impossible for secondary wholesalers. Prescription Drug Marketing Act of 1987: Hearing on S. 368 and H.R. 1207 Before the Subcomm. on Int'l Trade of the S. Comm. on Finance, 100th Cong. 49 (1987) (statement of Ronald J. Streck, Vice President, National Wholesale Druggists Association).

50. The manufacturer Smith Kline \& French protested the pedigree requirement in an October 3 , 1988, letter to the FDA. EBAN, supra note 4, at $385 \mathrm{nn} .162-63$.

51. Pedigree requirements were explicitly defined by regulation by the FDA in 21 C.F.R. $\S \S 203.1-.60$.

52. On August 1, 1988 the FDA issued a guidance letter setting forth the agency's preliminary views regarding the industry's responsibilities under the PDMA. The letter stated that to be an "authorized distributor," the type of ongoing relationship that needed to exist was only a "continuing business relationship in which it is intended that the wholesale distributor engage in wholesale distribution of a manufacturer's prescription drug product or products." Letter from Daniel L. Michels \& Thomas S. Bozzo, Directors, Food \& Drug Administration Office of Compliance, to Regulated Industry and Other Interested Persons (Aug. 1, 1988), available at http://www.fda.gov/oc/pdma/report2001/attachment-e.pdf. By stating that drug wholesalers only had to comply with existing recordkeeping practices of the industry, the FDA stayed the enforcement of a pedigree requirement, which wholesalers had never made an industry practice:

The new law's requirements for State licensing of wholesale drug distributors and the attendant requirements for minimum standards for recordkeeping, storage, and handling of prescription drugs pose potential economic implications for wholesale drug distributors. Although the statute itself does not specify these minimum standards, Congress clearly intended that these standards match currently recommended practices within the wholesale drug sector. The recommendation by the House of Representatives' Committee on Energy and Commerce for FDA to consider the Guidelines for the Inspection of Wholesales issued by the NABP provided explicit guidance on the specifications for these standards. FDA sought to conform the proposed minimum standards with the NABP guidelines and NWDA's-related proposed uniform standards by limiting modifications to conformance with current language and to clarifications required for consistency with existing drug regulations. Thus, the proposed minimum standards are intended to mirror recommended practices already existing among drug wholesalers.

The agency is not aware of the degree to which drug wholesalers comply with the various existing guidelines, but the agency believes that these represent the norm of current practices and procedures among drug wholesalers.

Guidelines for State Licensing of Wholesale Drug Distributors, 53 Fed. Reg. 35325, 35327 (Sept. 13, 1988) (to be codified at 21 C.F.R. pt. 205). 
administratively negated the full pedigree requirement five times over nearly twenty years. ${ }^{53}$ On June 9, 2006, the FDA announced that it was lifting the stay on implementation of pedigrees, effective December 6, 2006. ${ }^{54}$ Even though numerous documented cases of counterfeit drugs had come to light,,$^{55}$ the agency claimed it was lifting the stay because of the availability of technology to help distributors comply with pedigree requirements and because small wholesalers were no longer voicing complaints about compliance with the pedigree regulation. ${ }^{56}$

Sadly, a fully implemented federal pedigree requirement is still not a reality. In RxUSA Wholesale, Inc. v. Department of HHS, secondary wholesalers, which would not qualify as "authorized distributors" under the PDMA, alleged that implementation of the pedigree requirement by FDA regulations at section 203.50, the PDMA, or the two in conjunction, was an unconstitutional violation of the Equal Protection and Due Process clauses of the Fourteenth Amendment. ${ }^{57}$ The wholesalers argued that the pedigree regulation constituted disparate treatment in violation of the Equal Protection Clause in as much as it arbitrarily and capriciously required non-authorized distributors to trace products back to the manufacturer while exempting authorized distributors, thus preventing non-authorized distributors from conducting business. ${ }^{58}$ In addition, the wholesalers argued that FDA regulations at section 203.50 (interpreting the PDMA) violated the Due Process Clause by requiring only non-authorized distributors to source ${ }^{59}$ a drug to the manufacturer. They contended that the regulation had no rational relation to any legitimate state interest and was an erroneous interpretation of

53. EBAN, supra note 4, at 386 n.165. The FDA finally promulgated a final rule regarding implementation of the pedigree in 1994, which required non-authorized distributors to include the name of each business who sold the drug starting with the manufacturer. 21 C.F.R. $\S 203.50$ (2007).

54. In its press release, the FDA stated that in an effort to protect the public from counterfeit drugs, "the FDA will fully implement regulations related to the Prescription Drug Marketing Act of 1987, which requires drug distributors to provide documentation of the chain of custody of drug products - the so-called 'pedigree'- throughout the distribution system." Press Release, U.S. Food \& Drug Administration, FDA Announces New Measures to Protect Americans from Counterfeit Drugs (June 9, 2006), available at http://www.fda.gov/bbs/topics/NEWS/2006/NEW01386.html [hereinafter FDA News].

55. Katherine Eban's book, Dangerous Doses, had been published in 2005, and Dateline had done several reports in 2005 and 2006. See supra note 4.

56. The FDA claimed it had not received many complaints from small wholesalers about the impact of requiring pedigrees and finally recognized it could no longer justify delaying the requirement. FDA News, supra note 54

57. Complaint at 14, RxUSA Wholesale, Inc. v. Dep't of Health \& Human Servs., 467 F. Supp. $2 d$ 285 (E.D.N.Y. 2006) (No. 06-506).

58. Id. at 14-16.

59. To "source" means to identify the sales history of a drug. 
the PDMA, which requires that wholesale customers be informed of "all prior sales of the product." ${ }^{60}$

On November 30, 2006, seven days before the long-anticipated effective date of a federal pedigree requirement, the District Court for the Eastern District of New York issued a preliminary injunction staying the implementation of the federal pedigree requirement. ${ }^{61}$ The court disregarded the government's anemic laches claim (that it would suffer prejudice if the court delayed the implementation of the pedigree rule) given that the FDA itself had delayed the rule's implementation for so long. ${ }^{62}$ Regrettably, no other federal legislation currently requires pedigrees in the distribution chain. ${ }^{63}$ The need for a fully implemented PDMA is apparent. ${ }^{64}$

If federal pedigrees become mandatory, the definition of what qualifies as an exempt "authorized distributor" under the PDMA is nevertheless too broad to provide real protection to consumers. Under the PDMA, an "authorized distributor" is exempt from having to produce any pedigree when transacting pharmaceuticals. ${ }^{65}$ In 1999, the FDA promulgated its final rule and deemed that, without receiving any further governmental scrutiny, an "authorized distributor" is anyone with an "ongoing relationship" with a

60. According to the complaint, because the FDA had maintained a nearly twenty-year "status quo" of not requiring non-authorized distributors to produce pedigrees sourcing a drug back to the manufacturer, to now require wholesalers to do that would be erroneous. Complaint at 17-18, RxUSA, 467 F. Supp. $2 \mathrm{~d}$ 285.

61. The court reasoned that the preliminary injunction was merely a "temporary reprieve of the Rule taking effect." RxUSA Wholesale, Inc. v. Dep’t of Health \& Human Servs., 467 F. Supp. 2d 285, 307 (E.D.N.Y. 2006).

62. $I d$.

63. On May 12, 2005, Representative Steve Israel (D-NY) introduced “Tim Fagan's Law” which would have made pedigrees on the federal level mandatory and given the FDA investigatory subpoena power as well as the authority to increase criminal penalties for counterfeiting. H.R. 2345, 109th Cong. (2005). The bill continues to languish in the House Energy and Commerce Subcommittee on Health. The Library of Congress, THOMAs, http://thomas.loc.gov (select "109th Congress" and search bill number "H.R. 2345"; then view "All congressional actions") (last visited Jan. 23, 2008).

64. The known threat of counterfeit drugs that spawned only a handful of investigations in the $1990 \mathrm{~s}$ now has jumped nearly five-fold. Afia K. Asamoa, Not as Easy As It May Appear: Using Radio Frequency Identification Technology to Fulfill the Prescription Drug Marketing Act's Elusive Pedigree Requirement, 61 Food \& Drug L.J. 385, 385 (2006) (citing FDA Report 2004, supra note 1).

65. 21 C.F.R. $\$ 203.50$ (a) (2007) provides, in part:

Identifying statement for sales by unauthorized distributors. Before the completion of any wholesale distribution by a wholesale distributor of a prescription drug for which the seller is not an authorized distributor of record to another wholesale distributor or retail pharmacy, the seller shall provide to the purchaser a statement identifying each prior sale, purchase or trade of such drug.

The regulation goes on to specify what information shall be contained in that identifying statement. See id. 
manufacturer. ${ }^{66}$ Thus, no governmental entity exercises oversight in certifying which entities are "safe enough" to be trusted without a traceable history of distribution. Even when the FDA issued guidance documents for the drug industry regarding compliance with the PDMA in 2006, the nonbinding recommendations provided no additional procedures to clearly identify an authorized distributor of record.$^{67}$ Ironically, even the Healthcare Distribution Management Association (HDMA) - the lobbyist organization for wholesale distributors - noted that the definition of an authorized distributor under the PDMA should be enhanced to make any current pedigree requirements meaningful. ${ }^{68}$

66. The regulations define an "authorized distributor" as a "distributor with whom a manufacturer has established an ongoing relationship to distribute such manufacturer's products." Id. § 203.3(b). An "ongoing relationship" is further defined in $\S 203.1(\mathrm{u})$ as the following:

Ongoing relationship means an association that exists when a manufacturer and a distributor enter into a written agreement under which the distributor is authorized to distribute the manufacturer's products or a period of time or for a number of shipments. If the distributor is not authorized to distribute a manufacturer's entire product line, the agreement must identify the specific drug products that the distributor is authorized to distribute.

67. In responding to the question, "What information should be in the written agreement between a manufacturer and an ADR?," the FDA merely reiterated the definition of "ongoing relationship" contained $\S 203.3(u)$. U.S. Food \& Drug Admin., Guidance for the Industry: Prescription Drug Marking ACt (PDMA) REQUiREMENTS, QueSTIONS AND ANSwers 4 (2006), available at http://www.fda.gov/ OHRMS/DOCKETS/98fr/06d-0226-gd10003.pdf.

68. In a press release posted on its website on June 9, 2006, following the FDA lifting the stay on the federal pedigree requirement, the HDMA suggested changing the definition of "authorized distributor" and "distributor" in general to the following:

"Authorized Distributor of Record" means a drug distributor with whom a manufacturer has established an ongoing relationship to distribute the manufacturer's product. An ongoing relationship is deemed to exist when a drug distributor, including any affiliated group, as defined in Section 1504 of the Internal Revenue Code, of which the distributor is a member:

a) Is listed on the manufacturer's list and the list is updated monthly, or

b) Has a written agreement currently in effect with the manufacturer, or

c) Has a verifiable account with the manufacturer and minimal transaction or volume requirement thresholds as follows: 5,000 sales units per company within twelve (12) months or twelve (12) purchases (invoices) from the manufacturer within twelve (12) months.

"Distribution or wholesale distribution" means the distribution of prescription drugs to persons other than a consumer or patient, but does not include:

a) Intracompany sales;

b) The purchase or other acquisition by a hospital or other health care entity that is a member of a group purchasing organization of a drug for its own use from the group purchasing organization or from other hospitals or health care entities that are members of such organizations;

c) The sale, purchase, or trade of a drug or an offer to sell, purchase, or trade a drug by a charitable organization to a nonprofit affiliate of the organization to the extent otherwise permitted by law;

d) The sale, purchase, or trade of a drug or an offer to sell, purchase, or trade a drug among 


\section{B. State Law Attempts to Source the Drug Distribution Chain}

Faced with a federal pedigree requirement effectively stuck in purgatory, some states did undertake the burden of attempting to craft meaningful protection for consumers against counterfeit, adulterated, and fake medicines. Florida ${ }^{69}$ Nevada ${ }^{70}$ California, ${ }^{71}$ and New York $^{72}$ led the nation in attempting

hospitals or other health care entities that are under common control;

e) The sale, purchase, or trade of a drug or an offer to sell, purchase, or trade a drug for emergency medical reasons;

f) The sale, purchase, or trade of a drug, an offer to sell, purchase, or trade a drug, or the dispensing of a drug under a prescription executed in accordance with section _ of this chapter;

g) The distribution of drug samples by manufacturers' and authorized distributors' representatives;

h) The sale, purchase, or trade of blood or blood components intended for transfusion;

i) Drug returns, when conducted by a hospital, health care entity, or charitable institution in accordance with section of this chapter or the Boards'/Departments' regulations; or

j) The sale of minimal quantities of drugs by retail pharmacies to licensed practitioners for office use.

"Distributor or wholesale distributor" means any person engaged in the distribution of prescription drugs, including, but not limited to, manufacturers; repackers; own-label distributors; private-label distributors; jobbers; brokers; warehouses, including manufacturers' and distributors' warehouses, chain drug warehouses, and drug warehouses; and retail pharmacies that conduct drug distributions as defined in this section.

Healthcare Dist. Mgmt. Assoc., Recommendations for Enhancing the Domestic Prescription Drug Supply Chain 2-3 (2004), available at http://www.healthcaredistribution.org/gov_affairs/pdf_anti/HELP Com_alternatives.doc.

69. See Prescription Drug Protection Act of 2003, 2003 Fla. Laws 155.

70. Nevada enacted the toughest controls in the country regarding who can qualify as a wholesaler in the state, thereby attempting to squeeze out the criminal element in the entire shadow market. Gilbert M. Gaul \& Mary Pat Flaherty, Nevada Gets Tough, With Mixed Results, Wash. Post, Oct. 22, 2003, at A16. An owner of a wholesaler must submit his own fingerprints, employ an authorized representative with 6,000 hours of experience, and provide a complete list of employees/agents. Id. Only if a corporation is publicly traded is the owner exempt from the fingerprinting and employee list requirements. NEv. ADMIN. CODE $§ 639.593$ (7) (2007). Although the regulation shoved many wholesalers out of state, Nevada by itself cannot clean up the nation's distribution problems. Wholesalers merely moved across state lines and continued to distribute bad medicine into the porous national drug supply. Gaul \& Flaherty, supra note 6. However, Nevada did enact a stringent pedigree requirement, requiring wholesalers to pass pedigrees when the wholesaler is either (1) not an authorized distributor of a medicine or (2) when a wholesaler bought a drug from a source other than the manufacturer. See Nev. Admin. Code $§ 639.603$ (1) (2007).

71. California has repeatedly delayed implanting a comprehensive state pedigree law, having just this year pushed the state law's implementation date back to January 1, 2011. Press Release, California Bd. of Pharmacy, Decision of the California State Board of Pharmacy Pursuant to Business \& Professions Code Section 4163.5 (Mar. 25, 2008), available at http://www.pharmacy.ca.gov/laws_regs/delay_ implementation.pdf. The Board acquiesced to widespread industry complaints regarding the difficulty of 
to pass laws and administrative regulations cracking down on the secondary wholesale market. Among all of these states, Florida initially appeared to be a shining example of regulation.

Florida's legislative experience, however, proved disappointing and ineffective. In 2003, the Seventeenth Statewide Grand Jury in Florida issued a scathing report summarizing the great danger posed when counterfeiters and diverters infiltrate the legitimate distribution stream of prescription drugs. ${ }^{73}$ The Florida legislature embraced the Grand Jury's recommendation for a strong state pedigree law. ${ }^{74}$ It passed the Prescription Drug Protection Act of

meeting the state law's requirements. California had accepted the same industry argument concerning the industry's inability to meet California's requirement that every drug carry an electronic pedigree (a pedigree that could be tracked and verified through electronic means) when it delayed implementation of the law until 2009 from its prior implementation date of 2007. See Beth Bacheldor, Cardinal Health Deploying E-Pedigree System, RFID J., May 8, 2007, available at http://www.rfidjournal.com/article/articleview/ 3295/1/1; see also CAL. Bus. \& Prof. Code $§ 4163$ (West 2007), as amended by 2006 Cal. Legis. Serv. 658 (West). In their presentation to the FDA in 2006, Patricia Harris, Executive Director, and Judi Nurse, Pharm D Supervising Inspector, indicated that the California Board of Pharmacy may delay implementation of the wholesale drug pedigree until January 1, 2008. Patricia Harris \& Judi Nurse, Cal. Bd. Pharmacy, California Prescription Drug Pedigree (Feb. 27, 2006) (presentation slides available at http://www.fda.gov/ oc/meetings/rfid/nurse.ppt).

72. On May 31, 2006, New York State Assemblywoman Amy Paulin and Senator Nick Spano introduced companion legislation to increase the penalties for counterfeiting medication. Press Release, Amy Paulin \& Nick Spano, Assemblywoman Amy Paulin \& Senator Nick Spano Call for Tougher Laws to Prevent the Sale of Counterfeit Drugs (May 31, 2006), available at http://www.turkewitzlaw.com/ Counterfeit-Drug-2.pdf. On May 31, 2006, the bill was amended and recommitted to the higher education subcommittee where it died once the legislative session ended. Assemblywoman Paulin has since proposed similar legislation to help stop the sale and distribution of counterfeit drugs. New York State Assembly, Bill Summary of A07810, http://assembly.state.ny.us/leg/?bn=A07810 (last visited Jan. 23, 2008). Companion legislation has also been introduced in the New York State Senate. New York State Assembly, Bill Summary of S05290, http://assembly.state.ny.us/leg/?bn=S05290 (last visited Jan. 23, 2008).

73. The Grand Jury noted that tainted drugs move easily through the national drug distribution chain because of the failure of state and federal agencies to enforce the law and because of the "complicity of the wholesalers who turn a blind eye to the corrupt practices of other wholesalers that supply them with some of their pharmaceuticals." Supreme Court of the State of Florida, First Interim Report of the SEVEnTEEnTH StATEWIDE GRAND JuRy 3 (2003), available at http://myfloridalegal.com/grandjury17.pdf [hereinafter First InTERIm RePORT OF GRAND JURY]. The Grand Jury also noted that the 422 wholesale distributors of drugs in Florida who bought and sold drugs amongst themselves before passing them on to dispensing entities permitted an "alarming percentage" of illegally purchased drugs from the black market. Id. at 2. The Grand Jury further noted that many of the wholesalers in Florida were "unqualified, inexperienced, irresponsible and incompetent." Id.; see also Supreme Court of the State Of Florida, Second Interim Report of the Seventeenth Statewide Grand Jury (2003), available at http://myfloridalegal.com/interimjury17.pdf(illustrating the millions of dollars the Medicaid program was losing as Medicaid recipients and corrupt infusion clinics resold Medicaid medication to the black market, all of which was illegally reintroduced into the wholesale distribution system).

74. First INTERIM REPORT OF GRAND JURy, supra note 73. 
$2003,{ }^{75}$ which amended many provisions of the Florida Drug and Cosmetic Act. ${ }^{76}$ In addition to strengthening licensing requirements for wholesalers ${ }^{77}$ and increasing felony penalties for counterfeiter-diverters ${ }^{78}$ and non-compliant wholesalers, ${ }^{79}$ the state expanded its administrative rule requiring pedigree papers to travel with the most "vulnerable drugs" in the state

75. 2003 Fla. Laws 155.

76. Fla Stat. AnN. $§ 499.001-.081$ (West 2007).

77. The legislative history of this section evidences an intent to severely curtail who might qualify as a wholesaler in the state and refers in its preamble to the changes made by the 2003 Prescription Drug Protection Act:

Legislative findings and intent.-Based on the report of the Seventeenth Statewide Grand Jury in its First Interim Report the Legislature finds that prescription drugs brought into the state by wholesalers are being relabeled and falsely represented as being of a higher dosage by other wholesalers in order to charge higher prices for those drugs and that counterfeit substances labeled as genuine pharmaceuticals are being distributed, thereby causing an extreme danger that persons eventually receiving the drugs by prescription are receiving ineffective drugs in nontherapeutic doses, or even receiving dangerous or unwholesome substances, with the result that the health and well-being of the public is at risk. The Statewide Grand Jury also found that the lack of an effective pedigree paper requirement has resulted in the inability of prescription drug users to have confidence in the purity and efficacy of the drugs they use. The Statewide Grand Jury further noted that present laws do not allow effective criminal prosecution of persons involved in such false representations. It is the intent of the Legislature that the statutory changes and recommendations outlined in the Statewide Grand Jury's report be implemented as provided by this act. Id. $\S 2$.

78. The legislature elevated all criminal offenses relating to counterfeit and adulterated drugs to felonies of the second degree or higher. See Fla. Stat. AnN. § 499.0691 (West 2007).

79. See id. § 499.005. Revisions to the Prescription Drug Protection Act made unlawful both the failure to obtain a pedigree paper and the receipt of prescription drugs without pedigree papers. See id. $\S 499.005$ (27)-(28). The good-faith defense (set forth below), previously contained in $\S 499.005(7)$, was also eliminated:

The giving of a false guaranty or false undertaking with respect to a drug, device, or cosmetic, except by a person who relied on a guaranty or undertaking to the same effect signed by, and containing the name and address of, the person residing in this state from whom she or he received in good faith the drug, device, or cosmetic.

See Prescription Drug Protection Act of 2003, 2003 Fla. Laws 155, § 4.

80. Before recent amendments, the Florida Department of Health had the power to require wholesalers to provide complete pedigrees, including all prior sales and unique identifying lot numbers, of drugs on a "specified list." FLA. STAT. ANN. § 499.0121(6)(e) (West 2005) (current version at Fla. Stat. ANN. § 499.0121(6)(d) (West 2007)). The department could place a drug "on the list of specified drugs if the department [had] seized or issued a stop sale notice on the . . drug because of adulteration, counterfeiting or diversion of the prescription drug from" legal distributions channels, or if the FDA or another government regulator "responsible for the sale or distribution of prescription drugs in another state has notified the department" of such contamination of a drug in the legitimate marketplace, so long as the prescription drug satisfied one of the following criteria:

(I) The prescription drug is included among the top 150 prescription drugs for which the state has incurred the highest amount of Medicaid claims in the most recently ended state fiscal year; (II) The prescription drug is available for normal prescription use in dosages or strengths that 
have a wholesale cost of $\$ 200$ or more;

(III) The prescription drug is used extensively for patients with human immune deficiency virus, acquired immune deficiency syndrome, cancer, or other serious, life-threatening conditions, where drug non-responsiveness would not be considered to be medically unusual;

(IV) The prescription drug is an injectible drug;

(V) The prescription drug is subject to a special, limited distribution process and is not generally old to wholesale distributors by the manufacturer of the prescription drug;

(VI) The department has found not less than five instances where statements required pursuant to paragraph (d) for the prescription drug were not passed on other than because of unintentional oversight, or have been passed on by or to a wholesale distributor and such statements were fraudulent; or

(VII) A shipment of a prescription drug has been reported to a law enforcement agency as having been stolen or as missing.

Id. § 499.0121(6)(e)(3)(a) (West 2005) (current version at § 499.0121(6)(d)(5)(b)(1)(I)-(IV) (West 2007)). The Department of Health, after consultation with the Drug Wholesaler Advisory Council, would promulgate a rule placing drugs on the "specified drug" list. Id. § 499.0121(6)(e)(3)(b) (West 2005) (current version at $\S 499.0121(6)$ (West 2007)). The list of specified drugs appears in Florida's Administrative Code. Fla. Admin. Code AnN. r. 64F-12.001(2)(y) (2007). That list includes:

1. Bextra (valdecoxib);

2. Celebrex (celecoxib);

3. Combivir (lamivudine/zidovudine);

4. Crixivan (indinavir sulfate);

5. Diflucan (fluconazole);

6. Epivir (lamivudine);

7. Epogen (epoetin alfa);

8. Gamimune (globulin, immune);

9. Gammagard (globulin, immune);

10. Immune globulin;

11. Lamisil (terbinafine);

12. Lipitor (atorvastatin calcium); (fully effective $3 / 29 / 2004$ )

13. Lupron (leuprolide acetate);

14. Neupogen (filgrastim);

15. Nutropin AQ (somatropin, e-coli derived);

16. Panglobulin (globulin, immune);

17. Procrit (epoetin alfa);

18. Retrovir (zidovudine);

19. Risperdal (risperidone);

20. Rocephin (ceftriaxone sodium);

21. Serostim (somatropin, mannalian derived);

22. Sustiva (efavirenz);

23. Trizivir (abacavir sulfate/lamivudine/zidovudine);

24. Venoglobulin (globulin, immune);

25. Viagra (sildenafil citrate);

26. Videx (didanosine);

27. Viracept (nelfinavir mesylate);

28. Viramune (nevirapine);

29. Zerit (stavudine);

30. Ziagen (abacavir sulfate);

31. Zocor (simvastatin); 
by requiring pedigree papers to accompany all drugs. ${ }^{81}$ The term "pedigree" under Florida law was strictly defined as a document containing the sales information and lot number of the prescription drug. ${ }^{82}$ The document was to begin with the sale from the manufacturer and was to include all subsequent sales information until the drug was dispensed to a patient. ${ }^{83}$

Unfortunately, Florida's stringent pedigree requirement never went into effect. The effective date of the newly defined pedigree was to be July 1 , $2006,{ }^{84}$ but pharmaceutical manufacturers and distributors mounted an assault on Florida's 2006 legislative session to make sure that the requirement would not become effective. ${ }^{85}$ At their urging, the Florida legislature amended the definition of what qualified as a pedigree, tacking that alternate definition to a free-cancer-drug donation bill. ${ }^{86}$ The new provision alternatively defined a

\footnotetext{
32. Zofran (ondansetron);

33. Zoladex (goserelin acetate); and

Id.

34. Zyprexa (olanzapine).

81. Fla. STAT. $\$ 499.0121(6)(e)(1)$ (West 2005) (current version at $\$ 499.0121(6)(d)$ (West 2007)).

82. "Pedigree paper" means:

Effective July 1, 2006, a document in a form approved by the Department of Health and containing information that records each distribution of any given legend drug, from sale by a pharmaceutical manufacturer, through acquisition and sale by any wholesaler or repackager, until final sale to a pharmacy or other person administering or dispensing the drug. The information required to be included on a legend drug's pedigree paper must at least detail the amount of the legend drug, its dosage form and strength, its lot numbers, the name and address of each owner of the legend drug and his or her signature, its shipping information, including the name and address of each person certifying delivery or receipt of the legend drug, and a certification that the recipient has authenticated the pedigree papers. It must also include the name, address, telephone number and, if available, e-mail contact information of each wholesaler involved in the chain of the legend drug's custody. The department shall adopt rules and a form relating to the requirements of this paragraph no later than 90 days after the effective date of this act.

Id. § 499.003(31)(b) (West 2005) (current version at § 499.003(31)(a)-(b) (West 2007)).

83. $I d$.

84. Id.

85. When I spoke in front of the Florida Senate Judiciary Committee on April 25, 2006, I was the only person present who testified against changing the law. Meanwhile, representatives from McKesson, Cardinal Health, and AmerisourceBergen sat with a bevy of lobbyists for other wholesalers and Representative Homan to register their objection to the pedigree requirement. The drug industry representatives stayed in Tallahassee until the pedigree law was changed some time after 11 p.m. on the very last day of the 2006 legislative session.

86. After H.R. 1397, 2006 Leg., Reg. Sess. (Fla. 2006) (regarding just pedigrees and drug distribution), H.R. 685, 2006 Leg., Reg. Sess. (Fla. 2006) (regarding the distribution of prescription drugs by veterinarians), and S. 926, 2006 Leg., Reg. Sess. (Fla. 2006) (regarding just pedigrees and distribution of prescription drugs), the drug industry, through House and Senate representatives, tacked the change in the pedigree requirement on to a free drug donation program for cancer patients in H.R. 371, 2006 Leg., Reg. Sess. (Fla. 2006) and S. 1310, 2006 Leg., Reg. Sess. (Fla. 2006).
} 
"pedigree" as merely a document which states the name and strength of a drug accompanied by a promise by the manufacturer that "this wholesale distributor purchased the specific unit of the prescription drug directly from the manufacturer." ${ }^{\text {87 }}$ This change eliminates the ability of law enforcement officers, customers, and agencies to find the source of counterfeit drugs using the unique lot number from the pedigree paper. ${ }^{88}$

Despite its steady support for the free-drug donation program throughout the legislative session, the American Cancer Society made a last-minute request to Florida Governor Jeb Bush to veto House Bill 371, because "the risks to cancer patients through any weakening of the state's tough prescription drug safety law appear to outweigh the benefits of a new program

87. The alternate definition of "pedigree" reads:

A statement, under oath, in written or electronic form, confirming that a wholesale distributor purchases and receives the specific unit of the prescription drug directly from the manufacturer of the prescription drug and distributes the prescription drug directly, or through an intracompany transfer, to a chain pharmacy warehouse or a person authorized by law to purchase prescription drugs for the purpose of administering or dispensing the drug, as defined in $\S 465.003$. For purposes of this paragraph, the term "chain pharmacy warehouse" means a wholesale distributor permitted pursuant to $\S 499.01$ that maintains a physical location for prescription drugs that functions solely as a central warehouse to perform intracompany transfers of such drugs to a member of its affiliated group as described in $\S 499.0121(6)(\mathrm{h}) 1$.

1. The information required to be included pursuant to this subparagraph must include:

a. The following statement: "This wholesale distributor purchased the specific unit of the prescription drug directly from the manufacturer."

b. The manufacturer's national drug code identifier and the name and address of the wholesaler and the purchaser of the prescription drug.

c. The name of the prescription drug as it appears on the label.

d. The quantity, dosage form, and strength of the prescription drug.

2. The wholesale distributor must also maintain and make available to the department, upon request, the point of origin of the prescription drugs, including intracompany transfers; the date of the shipment from the manufacturer to the wholesale distributor; the lot numbers of such drugs; and the invoice numbers from the manufacturer.

FLa. Stat. AnN. § 499.003(31) (West 2007).

88. The Seventeenth Statewide Grand Jury noted that the requirement that a wholesaler maintain receipts of sale and present them if asked for them was meaningless as the entire state of Florida had so few drug inspectors. See First Interim Report of Grand Jury, supra note 73, at 2, 18 ("There exists in Florida approximately 422 licensed wholesalers in the prescription drug industry. In addition, there are approximately 977 wholesalers outside of the state of Florida that are licensed by the State to ship prescription drugs into Florida."). Most states have only a handful of inspectors to monitor the practices of thousands of wholesalers that exist nationally. Gaul \& Flaherty, supra note 6, at A15. 
whose merits are not yet established." ${ }^{89}$ Sadly, Governor Bush signed the bill into law in June of 2006. ${ }^{90}$

As well-intentioned as they might be, individual state efforts alone will not secure the drug supply in the United States. ${ }^{11}$ Drugs move seamlessly among billion-dollar wholesalers, smaller wholesalers, and retailers throughout the United States. Drugs that originate in one state easily reach all parts of the country. ${ }^{92}$ A patchwork of conflicting state regulations will be cumbersome for the industry without ever uniformly ensuring the safety of medicine. ${ }^{93}$ A uniform legal theory, as well as a codified federal legal duty,

89. In a letter dated May 17, 2006, Michael Kasper, M.D., Chairman of the Board and President of the American Cancer Society wrote the following to Governor Bush:

The promise of a lesser financial burden to particularly needy cancer patients means little if the prescription drugs provided to them could put their lives in jeopardy. While the cancer drug donation program is a viable concept that could ease some financial worries for some cancer patients, the greater concern to our organization is overall patient safety. In other words, Governor, we feel that it is more important to save lives than to save money.

It truly disappoints us to be in a position to recommend that you veto a bill that includes a positive new tool in the fight against cancer, but we feel the greater good would be served by staying the course with the drug pedigree process in current statute.

Letter from Michael Kasper, M.D., Chairman of the Board/President, American Cancer Society, to John Ellis Bush, Governor of Florida (May 17, 2006) (on file with the American Cancer Society).

90. Florida House of Representatives, Bill Summary for H.R. 371, http://www.flhouse.gov/ Sections/Bills/billsdetail.aspx?BillId=32048\&SessionId=42 (last visited Jan. 23, 2008).

91. As of 2007, a number of states have begun to pass legislation regulating wholesalers in an attempt to curb counterfeiting. Such states include: Alabama, Illinois, Iowa, Kansas, Kentucky, Maryland, Massachusetts, Missouri, Montana, Nevada, New York, Oklahoma, Tennessee, Utah, Washington, and Wyoming. Nat'l Conference of State Legislatures, 2007 Prescription Drug State Legislation 5 http://www.ncsl.org/programs/health/drugbill07.htm\#CA (last visited Jan. 23, 2008). Many states have already passed some measure of wholesaler reform in 2007, including Arkansas, Colorado, Georgia, Indiana, North Dakota, South Dakota, Texas, and Wyoming. Id. Nevada remains a beacon of hope against counterfeiting as it has retained its pedigree requirement. Since January 1, 2007, Nevada has required wholesalers to utilize electronically transmitted pedigrees for all sales of drugs. Nev. Rev. Stat. AnN. $\S 639.540(3)$ (West 2007).

92. The FDA Counterfeit Drug Task Force noted the ability of bad drugs to reach all parts of the distribution system:

Investigations performed by Federal and State authorities have repeatedly shown the existence of illicit nationwide networks designed to capitalize on the inadequate due diligence performed by members of the drug distribution system in order to introduce potentially unsafe diverted and counterfeit drugs in the U.S. drug distribution system.

FDA INTERIM REPORT 2003, supra note 7, § 2(C). While manufacturers themselves may sell only to a handful of large distributors, the distributors buy drugs from other sources such as other distributors and small wholesalers. "[T] hese secondary market sales are the primary, if not exclusive means by which [tainted] drugs enter the bloodstreams of the unwary." deKieffer, supra note 32, at 329. Counterfeiter Michael Carlow, who lived in Florida and repackaged drugs in his laundry room, infected the drug supply of Missouri, Tennessee, and the national wholesaler Cardinal Health (at the very least). See supra note 31.

93. The gaps among conflicting state and federal regulations and the complexity of the labyrinth of 
is necessary to hold all parts of the drug distribution system accountable for patient injuries caused by circulating tainted medicine.

\section{The "Good Humor" of Prescription Drugs: The Non-Delegable Duty of Safe Distribution Which Manufacturers and All Distributors Should Bear}

Generally, manufacturers and distributors that are part of a business enterprise may escape liability for negligence occurring in their enterprise by making use of independent contractors. ${ }^{94}$ However, some courts have concluded that, as a matter of public policy, ${ }^{95}$ all the employers in an enterprise should be responsible for the torts of independent contractors "who are carrying out the work of the enterprise." ${ }^{96}$ A nondelegable duty may arise by statute, contract, or common law. ${ }^{97}$ The courts' imposition of a nondelegable duty presupposes that, in certain circumstances, the employer of the independent contractor is "in the best position to identify, minimize, and administer the risks involved in the contractor's activities." ${ }^{98}$

An employer of an independent contractor has a nondelegable duty of care for delegated work negligently performed by the contractor ${ }^{99}$ when the business enterprise engaged in is either (1) inherently dangerous ${ }^{100}$ or

those patchy regulations provide opportunities to introduce tainted drugs in areas with less stringent regulation. These drugs then flow undetected through the tributaries of the national distribution system. See deKieffer, supra note 32, at 330-31.

94. An employer who hires an independent contractor is generally not liable for the contractor's negligence. Restatement (Second) of Torts § 409 (1965); see also Pusey v. Bator, 762 N.E.2d 968, 972 (Ohio 2002) (stating that "an employer is generally not liable for the negligent acts of an independent contractor"); Sloan v. Atl. Richfield Co., 552 P.2d 157 (Alaska 1976) (holding that no wrongful death recovery should be imposed in favor of an employee of an independent contractor against the possessor/owner of land upon a theory of vicarious liability). But cf. Privette v. Super. Ct., 854 P.2d 721, 724 (Cal. 1993) (observing that the nonliability rule is "now primarily important as a preamble to the catalog of its exceptions" (citing Van Arsdale v. Hollinger, 437 P.2d 508 (Cal. 1968))).

95. Policy reasons have been the basis for creation of exceptions to the general premise of nonliability. See Privette, 854 P.2d at 724.

96. Dan B. Dobbs, The Law of Torts $\S 337$ (2000).

97. 41 Am. Jur. 2D, Independent Contractors $§ 43$ (1995); see also Majorowicz v. Allied Mut. Ins. Co., 569 N.W.2d 472, 476 (Wis. Ct. App. 1997). In fact, Congress could codify a nondelegable duty of safe distribution for both manufacturers and all distributors, adopting the same rationale articulated by courts in this section.

98. Wilson v. Good Humor Corp., 757 F.2d 1293, 1301 (D.C. Cir. 1985).

99. 41 AM. Jur. 2D, Independent Contractors $\S 43$ (2005).

100. DoвBs, supra note 96 , at $\S 337$. "Inherently dangerous" has also been defined as "unusually hazardous." See, e.g., Wilson, 757 F.2d at 1303. 
generically hazardous activity, ${ }^{101}$ or (2) poses a peculiar risk of substantial harm to the public absent special precautions. ${ }^{102}$ Although some courts have blurred the boundaries of nondelegable duties by defining an inherently dangerous or generally hazardous activity as an activity which poses a peculiar risk of substantial harm in the absence of special precautions, ${ }^{103}$ better reasoning keeps this category distinct. ${ }^{104}$ When an activity poses a great risk of harm to the public against which the public has little ability to protect itself because of the specialized knowledge involved in an industry, that activity should not need to be "inherently dangerous" to trigger a nondelegable duty.

A business enterprise is inherently dangerous if danger exists in doing the activity, regardless of the method used or how skillful the independent contractor may be at the given activity. ${ }^{105}$ Conversely, an activity is not inherently dangerous if proper precautions can minimize the risk of injury. ${ }^{106}$ Typically associated with strict liability, inherently dangerous work does not

101. Wilson, 757 F.2d at 1303-04 (holding that the nondelegable duty of care for inherently dangerous activity clearly applies to generically hazardous work, but is not limited to that category).

102. The Restatement (Second) of Torts clarifies the concept of a nondelegable duty when enterprise activity poses the special risk of physical harm:

One who employs an independent contractor to do work which the employer should recognize as likely to create during its progress a peculiar risk of physical harm to others unless special precautions are taken, is subject to liability for physical harm caused to them by the failure of the contractor to exercise reasonable care to take such precautions, even though the employer has provided for such precautions in the contract or otherwise.

Restatement (SECOND) OF TORTS $§ 416$ (1965).

103. "Work is inherently dangerous when it creates a peculiar risk of harm to others unless special precautions are taken.” Pusey v. Bator, 762 N.E.2d 968, 973 (Ohio 2002) (holding that hiring armed guards to protect property was inherently dangerous activity as the employer could foresee that an armed confrontation might be required to do the job). Some courts have blurred the distinction between work of a peculiar risk and inherently dangerous work when discussing the finding of a nondelegable duty. See, e.g., Privette v. Super. Ct., 854 P.2d 721, 723 (Cal. 1993) ("Under the peculiar risk doctrine, a person who hires an independent contractor to perform work that is inherently dangerous can be held liable for tort damages when the contractor's negligent performance of the work causes injuries to others.").

104. See Wilson, 757 F.2d at 1303 (reasoning that cases should be read to suggest that two distinct types of independent contractor activity can bring an employer within the nondelegable duty exception to vicarious liability).

105. See Restatement (Second) of Torts $\S 427 \mathrm{cmt}$. b (1965). The comment reads:

It is not, however, necessary to the employer's liability that the work be of a kind which cannot be done without a risk of harm to others, or that it be of a kind which involves a high degree of risk of such harm, or that the risk be one of very serious harm, such as death or serious bodily injury. It is not necessary that the work call for any special skill or care in doing it. It is sufficient that work of any kind involves a risk, recognizable in advance, of physical harm to others which is inherent in the work itself.

Id.

106. See id. $\S 427$. 
require negligence on the part of the independent contractor to render the principal directly liable. ${ }^{107}$

An activity represents a peculiar risk in situations where the activity will likely cause injury to others unless special precautions are taken. ${ }^{108}$ A peculiar risk includes a danger resulting directly from the work done and not from the collateral negligence of the contractor in the operative, easily controlled details of the work. ${ }^{109}$ However, no bright-line rule exists to define when an activity represents a peculiar risk. ${ }^{110}$ The peculiar risk must be foreseeable to the employer at the time of contracting, ${ }^{111}$ and the activity must present a probability of harm to others, not just a possibility. ${ }^{112}$ The peculiar risk doctrine differs from the general concept of a nondelegable duty in that a peculiar risk does not require abnormally great risk to render an employer vicariously liable for the negligence of a contractor. ${ }^{113}$

Because counterfeit medicine poses a peculiar risk of harm to patients, courts could hold that manufacturers of pharmaceuticals that sell to authorized distributors - who, in turn, buy and sell from other wholesalers - bear a nondelegable duty to ensure the safety and integrity of the medicines they peddle. ${ }^{114}$ Manufacturers and authorized distributors have contractual

107. Privette, 854 P.2d at 723 .

108. Restatement (Second) of Torts provides that a "peculiar risk" arises when a risk is "peculiar to the work to be done and aris[es] out of its character, or out of the place where it is to be done, against which a reasonable [person] would recognize the necessity of taking special precautions." Restatement (SECOND) OF TORTS $\S 413 \mathrm{cmt}$. b (1965).

109. Routine, predictable dangers are not peculiar risks, as employers can expect the contractor to follow recommended safety procedures to avoid routine dangers. In Sievers v. McClure, the court refused to hold an employer liable for the death of a contractor's employee, declining to characterize the danger of falling off of a sloped roof during a roofing contract as a "peculiar risk," because no reasonable mind could find that the risk of falling was abnormal for such a contract. 746 P.2d 885, 888-90 (Alaska 1987).

110. See Wilson v. Good Humor Corp., 757 F.2d 1293, 1304 n.10 (D.C. Cir. 1985); Red Roof Inns, Inc. v. Purvis, 691 N.E.2d 1341, 1344-46 (Ind. Ct. App. 1998) (analyzing the nature of the work and the conditions under which it was performed to determine whether the risk of a roofer falling off a roof is an ordinary or peculiar risk).

111. See E. Airlines v. Joseph Guida \& Sons Trucking Co., 675 F. Supp. 1391, 1395-96 (E.D.N.Y. 1987) (holding that the job of driving through an airport at night in order to deliver top soil was not an inherently dangerous activity for a truck driver).

112. See Pusey v. Bator, 762 N.E.2d 968, 973 (Ohio 2002) (“The exception does not apply, however, where the employer would reasonably have only a general anticipation of the possibility that the contractor may be negligent in some way and thereby cause harm to a third party.").

113. See Privette v. Super. Ct., 854 P.2d 721, 725 n.2 (Cal. 1993).

114. Authorized distributors and secondary wholesalers that buy directly from a contaminated source would be negligent themselves and thus bear direct liability. 
relationships with one another, ${ }^{115}$ and distributors frequently buy and sell medicines among themselves. ${ }^{116}$

Both inter-relationships appear very similar to the long-term, independent-contractor relationship between Good Humor Corporation and the vendors that sold its ice cream, ${ }^{117}$ providing an interesting analogy for courts to examine when considering vicarious liability claims against manufacturers and authorized distributors. In Wilson v. Good Humor Corp., a three-year-old child was struck and killed by traffic when she attempted to cross the street to a Good Humor truck that was vending ice cream by the side of the road. ${ }^{118}$ The court held that Good Humor (the employer) could be sued for the child's death given the peculiar risk involved in vending ice cream to children on busy, car-laden streets by trucks playing music to attract customers. ${ }^{119}$ Because Good Humor knew or had special reason to know of the risks to children that were likely to arise from selling ice cream in the street, it could be sued directly. ${ }^{120}$ Just as the vendors in Wilson performed the bulk of Good Humor's business in a setting of foreseeable peculiar risk-a curbside littered with children ${ }^{121}$ — drug distributors now perform the bulk of the drug manufacturers' business in a market filled with counterfeit, adulterated, and diverted drugs.

Just as Good Humor chose not to inform its vendors or take precautions against the known and specific dangers to children who purchase ice cream from its vendors, ${ }^{122}$ drug manufacturers and large distributors have chosen to disclaim responsibility and failed to take adequate precautions against the known and specific danger posed by fake drugs in the market. ${ }^{123}$

115. In order to be an "authorized distributor" under federal law, the distributor must have a contractual relationship with the manufacturer. 21 C.F.R. $\S \S 203.3$ (b), (u) (2007).

116. See supra note 17 and accompanying text.

117. Wilson v. Good Humor Corp., 757 F.2d 1293, 1306 (D.C. Cir. 1985); Contra Rivera v. Flav-ORich, 876 F. Supp. 373 (D.P.R. 1995). In Contra Rivera, the court held that an ice cream truck owner was not the ice cream manufacturer's "independent contractor," but merely a purchaser of its products. $876 \mathrm{~F}$. Supp. at 383-84. Thus, the manufacturer could not be liable for the alleged negligence of the truck owner's employee in connection with a child's fall from the truck. $I d$. The court reasoned that, despite the fact that the owner regularly purchased significant amounts of the manufacturer's products, the manufacturer had no control over the manner, means, or results of the owner's work, since no forward sales contract existed between the parties and the truck owner was not restricted from selling other manufacturers' products. Id.

118. Id.

119. Id. at 1305 .

120. $I d$.

121. Wilson, 757 F.2d at 1306 .

122. Id.

123. Instead, manufacturers and distributors have fought the establishment of a reasonable federal pedigree requirement for nearly twenty years and have engaged only in brief forays over the last two years 
Undoubtedly, given their substantial financial resources, manufacturers and large distributors have the best knowledge of the dangers of drug distribution. They are also in the best position to identify the precautions that are necessary to safely perform the job. ${ }^{124}$ This "top-down" approach to vicarious liability therefore ensures that those manufacturers and authorized distributors that unscrupulously barter for the lowest-cost drugs without taking precautions to ensure drug integrity and safety do not escape liability.

To protect themselves against vicarious liability and to satisfy their nondelegable duty of care, manufacturers and distributors would only need to take those special safety precautions that are readily available to them. ${ }^{125}$ Numerous such precautions exist to keep counterfeit, adulterated, and diverted drugs out of the legitimate stream of commerce. First, manufacturers and distributors could merely acquiesce to a pedigree requirement, either electronic or paper, beginning with the manufacturer and exempting no party in the chain of distribution. ${ }^{26}$ Many technologies - including lower cost solutions such as bar coding ${ }^{127}$ and covert encoded inks, ${ }^{128}$ as well as higher cost solutions like Radio Frequency Identification Technology (RFID) $)^{129}$ and

into "track and trace" technology that might record the distribution of drugs. Michael A. Gips, Drug Tracking Heats Up, Sec. Mgmt., May 2007, at 18, 18-19.

124. Wilson, 757 F.2d at 1306.

125. Although I do sit on the Advisory Board for Secure Symbology, this article does not advocate that any one of the listed options for improving the security of the drug supply should be mandatory or preferred by the courts, the FDA, or Congress. Companies should exercise their autonomy and select the safety procedure that meets their own corporate needs so long as it adequately safeguards patients' health.

126. This would stand in contrast to the current requirements which, if enforced, would still exempt manufacturers and all authorized distributors from a pedigree requirement. See 21 C.F.R. $\S 203.50$ (2007).

127. Secure Symbology provides unique, multi-dimensional bar codes that help track a drug to the point of sale for use on individual units of drugs, cases of drugs, pallets of drugs, and larger containers of drugs. Describing one of its products, the ESC System, the company states that:

Secure Symbology Inc.'s ESC System provides "track and trace" reliability from production to pharmacist, assuring consumer protection, while meeting the stringent compliance requirements of federal and state regulatory agencies. It accomplishes this by using globally accepted machine-readable bar code symbologies, and/or the emerging RFID technology, within the context of SSI's patented and novel utilization of construction, deconstruction, and reconstruction of databases.

Secure Symbology, Secure Health, http://securesymbology.com/health.asp (last visited Jan. 23, 2008).

128. Inksure Technologies stated that it offers a covert, encoded, machine-readable unique ink that a companion scanner detects during inventory control. Inksure Technologies, Inksure's Security Approach for Our Customers, http://www.inksure.com/default.asp?psys=solutions (last visited Jan. 23, 2008).

129. RFID is defined as the following:

[A] generic term for technologies that use radio waves to automatically identify people or objects. There are several methods of identification, but the most common is to store a serial number that identifies a person or object, and perhaps other information, on a microchip that is attached to an antenna (the chip and the antenna together are called an RFID transponder or 
DNA-embedding technologies ${ }^{130}$ —are now available for drug industry participants, enabling them to "track and trace" the source and distribution of medication and produce electronic pedigrees. ${ }^{131}$ A multi-pronged, layered use of multiple technologies and a mandatory pedigree requirement (without exempt parties) would provide the most security. ${ }^{132}$

Manufacturers and distributors are well aware of these technologies. The pharmaceutical companies even choose to dabble in technology pilot projects. ${ }^{133}$ Nonetheless, those same parties have failed to use any of the

an RFID tag). The antenna enables the chip to transmit the identification information to a reader. The reader converts the radio waves reflected back from the RFID tag into digital information that can then be passed on to computers that can make use of it.

RFID Journal, Frequently Asked Questions, http://www.rfidjournal.com/faq/16/49 (last visited Jan. 23, 2008). Hundreds of companies market one form of RFID product or another. See RFID Journal, Frequently Asked Questions, http://www.rfidjournal.com/faq/16/53 (last visited Jan. 23, 2008).

130. Applied DNA Sciences offers markers for implementation that uniquely identify a real product from a counterfeit. Describing its patented SigNature markers, the company stated:

[W] e use DNA segments from one or more botanical sources, rearrange them into unique encrypted sequences, and then implement one or more layers of anti-counterfeit techniques. Because the portion of DNA in a SigNature DNA Marker used to identify the marker is so minute, it cannot be detected unless it is replicated billions of times over, or amplified. This amplification can only be achieved by applying matching strands of DNA, or a primer, and PCR techniques to the SigNature DNA Marker. The sequence of the relevant DNA in a SigNature DNA Marker must be known in order to manufacture the primer for that DNA. Applied DNA Sciences, The SigNature Program, http://www.adnas.com/signature (last visited Jan. 23, 2008).

131. Electronic pedigrees can be produced once a manufacturer or distributor employs a tracker, such as a bar code or RFID, a data management base, and a communications mechanism to relay information to partners. See VeriSign, Supply Chain Information Center, http://www.verisign.com/global-consulting/ supply-chain-services/supply-chain-information/ (last visited Jan. 23, 2007). VeriSign markets an Electronic Pedigree Service that it states can manage these three components efficiently. Id. SupplyScape sells a computer software application, Supplyscape E-pedigree, which works in conjunction with other technology to produce pedigree papers electronically, cutting down the cost and amount of human hours necessary to provide source documentation for drugs. SupplyScape, Product Security e-Pedgree Overview, http://www.supplyscape.com/products/security/pedigree/index.html (last visited Jan. 23, 2008).

132. Purdue Pharma's model for tracking Oxycontin provides a useful model for tracing drugs:

Purdue Pharma's system consists of ultrahigh-frequency (UHF) tags and readers, device

management software, and data management software (Class 0 UHF tags and readers, Symbol

Technologies, Holtsville, NY; device-management software, Northern Apex Software, Fort

Wayne, IN; "Auto-ID" and "Event Manager" software from SAP AG, Walldorf, Germany).

This system interacts with the company's enterprise resource-planning system ("R/3 ERP," SAP

AG) and makes it possible to link each bottle of OxyContin to a specific case and pallet.

Hallie Forcinio, Tagging Tools to Provide E-Pedigree, Pharmaceutical Tech., Sept. 2, 2006, at 44, 44, available at $\mathrm{http} / / / \mathrm{www}$. pharmtech.com/pharmtech/article/articleDetail.jsp?id=371131.

133. Cardinal Health has begun a pilot project but expressed that until stakeholders across the industry achieve a global standard, it would have to rely on "direct distribution," which Cardinal did not further define. Pharmaceutical RFID Pilot Finds Promise, Problems, RFID Update, Nov. 15, 2006, http://www.rfidupdate.com/articles/index.php?id=1246 (last visited Jan. 23, 2008). AmerisourceBergen 
technologies in a widespread manner. Even the FDA has scolded drug manufacturers and distributors for not implementing readily available technological advances. ${ }^{134}$

The risk of counterfeit drugs reaching patients has long surpassed a mere possibility. ${ }^{135}$ In the wake of this reality, wholesalers still resist pedigree laws, ${ }^{136}$ and manufacturers continue to view wholesale distributors as their primary concern ${ }^{137}$ rather than worrying about the safety of patients. Patients should begin suing manufacturers and distributors for injuries caused by counterfeit drugs until the drug industry satisfies its nondelegable duty of care by implementing technological security measures and acquiescing to the full implementation of pedigrees. The drug manufacturers and distributors can satisfy their obligation to protect the public and cut off liability by merely implementing the special precautions that exist.

The drug industry is unique and well suited for the application of the peculiar risk doctrine. No other industry serves a population already

announced it would begin an RFID pilot project in December 2006. Innovative Track and Trace Program, Insights (AmerisourceBergen, Valley Forge, PA), Dec. 2006, at 1, 1, available at http://www .amerisourcebergen.com/cp/1/docs/related_resources/retail_pharmacies/INSIGHTS/Dec_06_ Insights_FINAL.pdf. Purdue Pharma exclaims that it is the only pharmaceutical company to "implement fully" an RFID "track and trace" program. Michael A. Gips, supra note 123, at 18, 18-19. However, Purdue Pharma has only fully implemented that system for a single drug, Oxycontin. Forcinio, supra note 132, at 44. In 2004 and 2005, Pfizer also conducted a year-long bar code and RFID pilot on the single drug Viagra. Tim Marsh, Viagra RFID: One Year Later, RFID Update, May 23, 2007, http://www.rfidupdate.com/articles/index.php?id=1366 (last visited Jan. 23, 2008). Even though the pilot was successful, Pfizer only announced plans to further implement the technology by tracking the single drug Viagra in pallet and case quantities. Id. Pfizer markets over 50 different name-brand medications. Pfizer, Pfizer Pharmaceutical Products, http://www.pfizer.com/products/rx/rx.jsp (last visited Jan. 23, 2008).

134. A recent Information Week article reported the following:

[P] harma's use of RFID today remains limited to a handful of test projects. An FDA report this month, while calling those efforts encouraging, chastises drugmakers, wholesalers, and retailers for being slow to implement "e-pedigree" systems such as bar codes or RFID to prevent drug counterfeiting. The report singled out RFID adoption in particular: "We are disappointed with the lack of overall progress across the drug supply chain."

Time for the pharmaceutical industry to pick up the pace, amid a growing number of FDA and state government mandates for drug pedigree systems.

Rick Whiting, FDA Scolds Drug Industry for Anemic RFID Adoption, INFo. WeEk, June 19, 2006, at 28, 28 available at $\mathrm{http}: / / \mathrm{www}$.informationweek.com/story/showArticle.jhtml?articleID=189500084.

135. See supra Section I.

136. See, e.g., RxUSA Wholesale, Inc. v. Dep't of Health \& Human Servs., 467 F. Supp. 2d 285 (E.D.N.Y. 2006), discussed supra pp. 255-56.

137. After I testified to the Senate Judiciary Committee in opposition of amending Florida's pedigree definition in 2006, a representative from Astra Zeneca said that, although she understood my concern about drug integrity, the manufacturer could not publicly oppose the will of distributors who wanted to water down the pedigree since "the distributors were [their] consumers." 
compromised by health conditions and so manifestly vulnerable. The dangers posed by counterfeit drugs range from death by poisoning, at the worst, to the ingestion of non-active ingredients by sick consumers, which itself can lead to a patient's decline, eventual illness, and even death. Additionally, the interrelationship of manufacturers - which as patent holders stand in a unique position as sole suppliers of a medicine or a group of medicines - and the distributors-which serve them further-illustrates the need for a special liability standard.

\section{V. “Going Green": Why Codifying a Strict Liability Standard for the Incidence of Counterfeit Drugs Makes Sense}

Beyond the vicarious liability option outlined above, another approach to secure the drug supply chain would be for Congress to enact legislation imposing strict liability on manufacturers and distributors for injuries caused by counterfeit drugs. Environmental laws already impose strict liability for injuries caused by the distribution of hazardous chemical byproducts of legitimate industry. ${ }^{138}$ These laws, driven by a concern for the public health, provide both an analogy and a blueprint for Congress to create a strict liability scheme for injuries caused by the distribution of counterfeit drugs which-like hazardous waste-are harmful chemicals representing the byproduct of a legitimate industry. ${ }^{139}$

138. See, e.g., Resource Conservation and Recovery Act, 42 U.S.C. $\S \S 6901-6992 k$ (2000); Comprehensive Environmental Response Compensation and Liability Act, 42 U.S.C. $\$ \S 9601-9675$ (2000).

139. The RCRA allows private citizens to bring suit against a past or present generator, operator, or owner who has contributed or is contributing to the handling, storage, treatment, transportation, or disposal of waste which may present an imminent and substantial endangerment to health or the environment. Id. $\S 6972(a)(1)(B)$. The EPA Administrator can bring similar suits under the RCRA when health is endangered. Id. $\S 6973$ (a). CERCLA also focuses on the threat to public health as the trigger for action, including when the President may abate activity which poses such a threat:

[W] hen the President determines that there may be an imminent and substantial endangerment

to the public health or welfare or the environment because of an actual or threatened release of

a hazardous substance from a facility, he may require the Attorney General of the United States

to secure such relief as may be necessary to abate such danger or threat. 42 U.S.C. $\$ 9606($ a) (2000). 
A. Strict Liability for Injury Caused by the Distribution of Harmful Chemical Byproducts

The RCRA governs the treatment, handling, and disposal of solid and hazardous waste. ${ }^{140}$ The purpose of the RCRA was to "empower[] [the] FDA to regulate hazardous wastes from cradle to grave, in accordance with . . . rigorous safeguards." ${ }^{141}$ The RCRA is largely a "forward looking" statute in that most of its provisions attempted to create a regulatory scheme for future storage, treatment, transport, and disposal of waste. ${ }^{142}$

In addition to promulgating a pro-active regulatory scheme, however, the RCRA establishes strict liability for past or present waste generators, transporters, owners, and treatment plant operators whose handling of waste may present an imminent and substantial endangerment to public health or the environment. ${ }^{143}$ The RCRA gives both the government and private citizens the right to seek judicial relief to avert imminent and substantial threats to the public health. ${ }^{144}$ The RCRA also allows the EPA or a private citizen to obtain an injunction when any person shows an endangerment to the public health. ${ }^{145}$ Congress intended the RCRA, as initially enacted and then as later amended in 1984 , to impose strict liability without reference to fault or negligence. ${ }^{146}$

140. See Meghrig v. KFC W., Inc., 516 U.S. 479, 483 (1996) (citing Chicago v. Envtl. Def. Fund, 511 U.S. 328, 331-32 (1994)). The definition of what constitutes hazardous waste in the environmental context is extensively governed by the RCRA itself and by EPA Guidance documents. See OfFICE OF Enforcement \& Compliance Assurance, U.S. Envtl. Prot. Agency, Guidance on the Use of SECTION 7003 OF RCRA 14-16 (1997), available at http://www.epa.gov/compliance/resources/ policies/cleanup/rcra/971020.pdf (superseding the Final Revised Guidance Memorandum on the Use and Issuance of Administrative Orders Under Section 7003 of the Resource Conservation and Recovery Act, which was issued by the E.P.A. on Sept. 26, 1984). This article presumes that counterfeit, adulterated, or diverted medicine is hazardous to human health because it does not, at the very least, meet FDA requirements for human consumption in its most innocuous form. Id.

141. Chicago v. Envtl. Def. Fund, 511 U.S. 328, 331 (1994).

142. Roger W. Findley \& Daniel A. Farber, Environmental Law in a Nutshell 191 (5th ed. 2000).

143. See 3 Susan M. Cooke, The Law of Hazardous Waste: Management, Cleanup, Liability, AND LitigATION § 15.01[3][a], at 15-6. (2001) (“[L]iability under Sections 7003 and 7002(a)(1)(B) attaches to any person who (1) has contributed or is contributing to (2) the past or present handling, storage, treatment, transportation, or disposal of (3) any solid or hazardous waste which (4) presents an imminent and substantial endangerment to health or the environment.").

144. The EPA would bring suit on these grounds under 42 U.S.C. $\S 6973$, while private citizens would bring such a strict liability suit under $\S 6972$. See 42 U.S.C. $\S \S 6972-73$ (2000).

145. Id.; see also United States v. Bliss, 667 F. Supp. 1298, 1313 (E.D. Mo. 1987).

146. Bliss, 667 F. Supp. at 1313. 
CERCLA is "backwards looking," as the provisions are not regulatory in nature and instead focus on creating broad civil liability for the cleanup of leaking sites of waste treatment, transport, storage, and disposal. ${ }^{147}$ CERCLA provides that the federal government, states, or private citizens may bring actions to recover costs incurred in responding to the release of hazardous substances. ${ }^{148}$ CERCLA joins the RCRA in imposing liability without regard to a liable party's fault or state of mind. ${ }^{149}$ Responsible parties may be jointly and severally liable, although liability may also be apportioned among defendants in appropriate cases. ${ }^{150}$ The intent of including a strict liability standard in CERCLA and not allowing parties to contract out of that liability was to ensure that economic power did not enable manufacturers to shift liability for harm to those transporting, distributing, or treating the hazardous material. ${ }^{151}$

147. See United States v. Ne. Pharm. \& Chem. Co., 810 F.2d 726, 740 (8th Cir. 1986) (holding that CERCLA applies retroactively and that the RCRA imposes strict liability upon past off-site generators and transporters of hazardous substances); see also Bliss, 667 F. Supp. at 1313 (stating that the RCRA imposes liability without fault or negligence and applies to present conditions resulting from the past activities of past off-site generators and transporters); CoOKE, supra note 143, § 15.01[4], at 15-13 n.55 (citing the congressional discussion of the standard "regardless of fault or negligence" and the statement that "nonnegligent generators whose wastes are no longer being deposited at a particular site may be ordered to abate the hazard to health or the environment posed by the leaking of the wastes they once generated and which have been deposited at the site." (citing H.R. ReP. No. 98-198, pt. 1, at 47-49 (1983), as reprinted in 1984 U.S.C.C.A.N. 5576, 5609-09)).

148. FINDLEY \& FARBER, supra note 142, at 191.

149. See Cooke, supra note 143, at § 14.01[1], 14-10.1-19.

150. Bliss, $667 \mathrm{~F}$. Supp. at 1313 (holding that the generators of waste, the company that arranged for the transportation of the waste, and the company which stored and sprayed oil on the container of waste were all jointly and severally liable for the expense of the government's cleanup of dioxin and TCP to abate the release of hazardous substances). But cf. United States v. A \& F Materials Co., 578 F. Supp. 1249, 1258 (S.D. Ill. 1984) (holding that Congress intended courts to apply the equities of each case when apportioning fault amongst defendants); see also CoOKE, supra note 143, at §14.01[2][c], at 14-20.

151. In United States v. Price, the court noted:

[T] he strict liability standard fits most closely with the legislative aims of CERCLA which include goals such as cost-spreading and assurance that responsible parties bear their cost of the clean up. The fulfillment of these Congressional goals is more likely to be effectuated if the defendants who allegedly contributed to the environmental mess are now held to a very stringent standard of liability. Though strict liability may impose harsh results on certain defendants, it is the most equitable solution in view of the alternative-forcing those who bear no responsibility for causing the damage, the taxpayers, to shoulder the full cost of the clean up.

577 F. Supp. 1103, 1114 (D.C.N.J. 1983) (citations omitted). With Senator Randolph concurring, Senator Cannon discussed why section 107(e)(1) was enacted, stating:

It is my understanding that this section is designed to eliminate situations where the owner or operator of a facility uses its economic power to force the transfer of its liability to other persons, as a cost of doing business, thus escaping its liability under the act all together. 
Utilizing the same public-health rationale that motivated the imposition of strict liability in both the RCRA and CERCLA, Congress could impose a strict liability scheme for manufacturers and distributors when counterfeit drugs pass through the legitimate distribution system and injure patients. The similarities between the two situations are manifold. The hazardous waste contemplated by the environmental statutes and fake medicine are both chemical compounds. Manufacturers of pharmaceutical drugs are similar to the generators of industrial waste which, when making their legitimate and valuable products, produce hazardous chemical byproducts. In the context of generators, the chemical product is the hazardous waste itself. In the pharmaceutical context, the high drug prices set by manufacturers entice profit-seeking criminals to pollute the drug stream, creating the social byproduct of counterfeit drugs. Just as Congress did not allow generators of hazardous waste to use their economic might to contract out of liability for hazards later caused by the disposal of that waste, so too should Congress hold manufacturers responsible for injuries caused by counterfeit drugs rather than allowing them to escape liability through the hiring of distributors.

Drug distributors should also be held jointly and severally liable for injuries caused by counterfeit drugs since those distributors are similar to the "transporters" of hazardous waste covered by the environmental statutes. ${ }^{152}$ Drug distributors can choose to buy medicine solely from manufacturers and thereby avoid sources which open doors for criminals to penetrate the drug supply. Instead, distributors try to increase their profits by engaging in pharmaceutical arbitrage, in some cases buying medicines at costs even lower than those offered by the manufacturers of those drugs. ${ }^{153}$ Like transporters who continually hauled waste to a contaminated landfill, ${ }^{154}$ distributors have continuously bought bad drugs from cheap suppliers, thereby reaping millions of dollars and perilously endangering lives. Moreover, distributors choose not

126 Cong. Rec. 30,984 (1980), reprinted in Mark E. Anthony Reisch, A Legislative History of the Comprehensive EnVironmental Response, Compensation, AND LiABILITy ACt of 1980, at 22 (1983). In discussing both the Senate and the House's three key concerns with hazardous substance legislation, Representative Florio stated that the "absence of negligence is not a defense to liability," as CERCLA would create a standard of strict liability qualified only by the narrow defenses contained within the statute itself. Id. at 24 (quoting 126 CoNG. ReC. 31,965 (1980)).

152. Section 107(a) of CERCLA clearly imposes liability on transporters who select a treatment and disposal site which later becomes hazardous. 24 U.S.C. § 9607(a)(4) (2000); United States v. Ne. Pharm. \& Chem. Co., 579 F. Supp. 823, 839, 844 (W.D. Mo. 1984) (confirming liability of transporters).

153. See supra Section II for discussion of authorized distributors' purchase practices.

154. See, e.g., United States v. Waste Indus., Inc., 734 F.2d 159 (4th Cir. 1984) (granting permanent injunctive relief after it was shown that Waste Industries' operation of a landfill over several years led to the burial of unknown quantities of solid and hazardous waste that contaminated the area's water supply). 
to employ new security measures such as bar coding or RFID, which makes their inventory susceptible to penetration by criminals if even one unscrupulous employee of a distributor allows a felon to introduce counterfeit drugs into a warehouse. ${ }^{155}$

A federal statute holding drug manufacturers and distributors jointly and severally liable could provide for both government-directed and private citizen suits. Following the RCRA's equitable remedy model, when the FDA or state pharmaceutical agencies discover that counterfeit drugs have been released into the legitimate drug supply, the statute could enable the FDA Commissioner or a private citizen to seek an injunction directing the manufacturer of the drug and all distributors to remove the lot number (or a series of lot numbers) from the marketplace. Additionally, following CERCLA's paradigm of seeking clean-up costs, a federal statute could allow the FDA and private citizens to recoup, when relevant, the costs of investigation, prosecution, and personal injury related to the counterfeit drugs.

\section{B. Defining an Imminent and Substantial Endangerment to Health}

Of critical importance to any proposed federal drug statute would be defining a trigger event indicating when counterfeit, adulterated, or diverted medicine presents an imminent and substantial endangerment to health. The RCRA's provisions allow the EPA or a private citizen to seek injunctive relief when hazardous waste "may present" an imminent and substantial endangerment to the environment. ${ }^{156}$ The inclusion of the terms "may present" signified Congress's intent to provide courts with broad equitable powers to abate any risk posed by toxic waste. ${ }^{157}$ However, the RCRA does not allow the EPA or a private citizen to enjoin hazardous waste activity when "the risk of harm is remote in time, completely speculative in nature, or de minimus in degree." 158

155. See, e.g., Indictment, United States v. Carlow, No. 3:06-00047 (M.D. Tenn. Mar. 29, 2006), available at $\mathrm{http}: / / \mathrm{www}$.dangerousdoses.com/pdf/Robert_Neil_Spence_Indictment\%5B1\%5D.pdf(alleging that Neil Spence, a single employee at Cardinal Health, enabled felon Michael Carlow to sell thousands of dollars worth of counterfeit drugs to the distributor which in turn sent the drugs out nationally to retailers).

156. The RCRA authorizes suit against those who handle hazardous waste in a manner which "may present an imminent and substantial endangerment to health or the environment." See 42 U.S.C. $\S \S 6972(a)(1)(B), 6973(a)(2000)$.

157. CоOKE, supra note 143, § 15.01[3][e], at 15-11 (citing United States v. Waste Indus., Inc., 734 F.2d 159, 166 (4th Cir. 1984)); see also United States v. Price, 688 F.2d 204, 213 (3d Cir. 1982); United States v. Valentine, 856 F. Supp. 621, 626 (D. Wyo. 1994)).

158. H.R. ReP. No. 93-1185, at 36 (1974), as reprinted in 1974 U.S.C.C.A.N. 6454, 6488. 
What constitutes an imminent and substantial endangerment under the RCRA is an inherently fact-specific question. ${ }^{159}$ The Supreme Court noted that an endangerment is "imminent" if it threatens to occur immediately, and the term implies that the danger must be a present threat, "although the impact of the threat may not be felt until later." 160 This "lenient standard"161 allows government intervention to prevent hazardous waste contamination from happening, although the latent harm to public health caused by the contamination might not be evident for a substantial period of time. ${ }^{162}$ Imminence must be construed with consideration of the time it takes for administrative and judicial action, including the preparation, issuance, and enforcement of administrative court orders to achieve the legislative purpose of protecting public health. ${ }^{163}$

CERCLA does not define within its own provisions what constitutes an "imminent and substantial" risk to public health. ${ }^{164}$ Actual harm need not have occurred before the government or a private citizen can seek relief; ${ }^{165}$ instead, a threatened or potential harm is sufficient to qualify as an endangerment. ${ }^{166}$ Under CERCLA, "a finding of endangerment requires the Court to evaluate the nature and degree of the risk posed by the hazardous substances." 167

For the proposed federal statute, Congress could implement the same standard to trigger strict liability that it wrote into the RCRA and CERCLA - circumstances which may present an imminent and substantial endangerment to health. In its guidance memoranda, the FDA could propose

159. COOKE, supra note 143, $§ 15.01[3][\mathrm{e}]$, at 15-11 (noting that the standard has not been thoroughly explored by the courts). The difficulties of interpreting this statutorily undefined standard were contemplated by my colleague, Joel A. Mintz. See Joel A. Mintz, Abandoned Hazardous Waste Sites and the RCRA Imminent Hazard Provision: Some Suggestions for a Sound Judicial Construction, 11 HARV. ENVTL. L. REV. 247 (1987).

160. Meghrig v. KFC W., Inc., 516 U.S. 479, 485-86 (1996).

161. Price, 688 F.2d at 211.

162. See id.; Cox v. Dallas, 256 F.3d 281, 299 (5th Cir. 2001).

163. H.R. REP. No. 93-1185, at 36 (1974), as reprinted in 1974 U.S.C.C.A.N. 6454, 6488.

164. United States v. Conservation Chem. Co., 619 F. Supp. 162, 192 (W.D. Mo. 1985) (lamenting that Congress gave no guidance as to the specifics of the factual circumstances that would constitute such a danger under CERCLA).

165. Id. at 193 ("Because endangerment entails only a threat of harm, the endangerment provisions 'have enhanced the courts' traditional equitable powers by authorizing the issuance of injunctions when there is but a risk of harm, a more lenient standard tha[n] [the] traditional requirement of threatened irreparable harm."' (quoting United States v. Price, 688 F.2d 204, 211 (3d Cir. 1982))).

166. Id. at 192 (citing Ethyl Corp. v. EPA, 541 F.2d 1 (D.C. Cir. 1976); Reserve Mining Co. v. EPA, 514 F.2d 492, 528 (8th Cir. 1975)).

167. United States v. Bliss, 667 F. Supp. 1298, 1314 (E.D. Mo. 1987). 
a list of non-exclusive factual scenarios which would highlight circumstances where an individual or the government should know that counterfeit drugs "may present" such an endangerment to public health, although no actual harm to health has yet occurred. During the course of federal or state investigations, the discovery of counterfeit, adulterated, or diverted medicine should be a sufficient trigger to enable the government or an individual to seek injunctive relief to abate future harm to consumers. Discovery of counterfeit drug labels should also trigger liability and action. Finally, when breaches of security at either manufacturing or distributing facilities are uncovered, the FDA or a citizen should have the power to ask a court to issue a recall of the tainted drug by petitioning for injunctive relief.

Certainly, a patient suffering actual harm from counterfeit drugs would satisfy the imminent and substantial endangerment standard. At that point, using CERCLA as the "clean up" model, a federal statute could allow the patient to recoup her or his personal injury damages and likewise permit the FDA to recover the costs of conducting a recall of the drugs pursuant to a court-issued injunction.

\section{CONCLUSION}

The FDA's Anti-Counterfeiting Task Force reports ${ }^{168}$ and state experiences with the outbreak of drug counterfeiting, contamination, and diversion ${ }^{169}$ demonstrate the risks posed to the public by tainted drugs. The use of independent contractors and the economic might of manufacturers and authorized distributors are no longer adequate justifications for exempting these parties from liability for injuries caused by tainted products. This Article suggested two paradigms of liability: Under one approach, vicarious liability would be judicially imposed based on manufacturers' and authorized distributors' nondelegable duty of safe distribution. Under another approach, Congress would espouse the commitment to protecting public health embodied in environmental laws by imposing strict liability in situations where tainted drugs may present an imminent and substantial endangerment to health. Either of these paradigms would enhance patient safety. The purchase of drugs from a multiplicity of sources because of low prices and the failure to take adequate precautions in an industry of peculiar risk should no longer be economical for corporations. The liability system should favor

168. See supra Section I.

169. See supra Sections I-III(B). 
protecting innocent, dependent patients over any corporate profit margin. Mahatma Gandhi best articulated the need for the prioritization of the public's well-being over monetary gain: "It is health which is real wealth and not pieces of gold and silver." 170

170. See Mem'l Hosp. v. Maricopa County, 415 U.S. 250, 259 n.14 (quoting President Nixon's use of Gandhi's quote in Richard Nixon, Health, Message from the President, H.R. Doc. No. 92-49, at 18 (1st Sess. 1971)). 